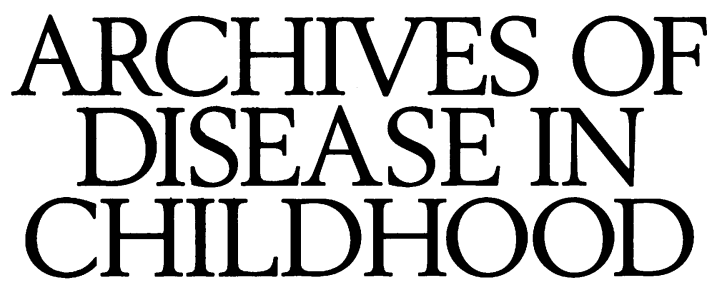

The Fournal of the British Paediatric Association

\title{
Annotation
}

\section{Violence in children: the scope for prevention}

Violence has been defined as behaviour by people against people likely to cause physical or psychological harm. ${ }^{1}$ All of us, including children and young people, have a capacity for violent behaviour. However, probably all of us also want to live in a non-violent society. This does not necessarily mean we want to live in a society that is non-competitive or that we hold pacifist beliefs. It does mean that we would like to eradicate violence, as defined, from family life, from schools, and from the neighbourhoods in which we live.

Most individuals who are violent in adulthood begin to show such behaviour in childhood. Although many aggressive children do not grow up to be violent adults, very few violent adults have failed to show such behaviour in childhood and adolescence. ${ }^{2}$ Consequently, those such as paediatricians, who are concerned with the health and behaviour of children, have a particular responsibility to consider what might be done to prevent violence.

In this review I shall first outline what we know of the causes of violence in children, and then describe what might be done in the way of rational prevention. Excellent more detailed reviews on causation ${ }^{3}$ and possibilities for prevention $^{4}$ are available. Although they are obviously relevant to any discussion of the subject, I shall omit reference to institutionalised forms of violence such as war, terrorism, and boxing.

\section{Causation of violence: background factors}

A simple cause and effect model for the development of violence in children and adolescence is inappropriate. The literature is replete with discussion of additive and interactive effects, and reverse causation. For example, a child with four psychosocial stresses in his background is a great deal more than four times more likely to show violent behaviour than a boy with one such stress. ${ }^{5}$ Exposure to media violence does have an effect on the propensity of boys to be violent, but aggressive boys are also more likely to watch action-packed videos and TV films. ${ }^{6}$ All this does not mean that as the whole situation is so complicated, no clear, useful evidence exists. It does mean that the results of studies have to be interpreted with caution for possible confounding effects.

(A) SOCIAL FACTORS

There is a link between violence and adverse social factors such as poverty, homelessness, and unemployment (in school leavers themselves as well as in parents). ${ }^{7}$ Relative deprivation is probably more important than absolute deprivation. The degree to which the link is causal is unknown, and the processes leading from adverse psychosocial circumstances to violent behaviour are not well worked out, but probably a number of mechanisms operate. There may be frustration because of inability to purchase the same as others; a lack of purpose in school attendance in high unemployment areas may lead to truancy and increased opportunities for crime; parental despair and preoccupation with making ends meet may impair the quality of child supervision, and lead to inconsistent discipline.

\section{(B) FAMILY FACTORS}

Probably nothing predisposes a child to violence more than the experience of violence in the home. Parents with aggressive, impulsive personalities are likely to abuse their children by using uncontrolled violence as a form of discipline, sometimes as the main form of discipline. ${ }^{8}$ Children brought up in this way are more likely to be aggressive themselves. (In passing it may be worth noting that when we hear or read about a teenager involved in some serious form of violence, such as joyriding in a stolen car and killing a pedestrian, our initial reaction is often to assume this would never have happened if the child had been 'properly' disciplined, that is beaten when he was disobedient. The reverse is the case. The use of severe physical punishment predisposes to such behaviour.)

On a more controversial issue, British parents use corporal punishment as a habitual form of discipline. A recent Department of Health supported study (M Smith, paper presented at the 5th European Conference on Child Abuse and Neglect, Oslo, Norway 13-16 May 1995) revealed that $91 \%$ of a sample of 400 children aged between 1 and 11 years had been hit, $77 \%$ in the last year. Altogether $15 \%$ had been severely physically chastised with the intention or potential to cause injury or psychological damage. It is generally agreed that an occasional smack in the context of a loving relationship does no harm. The problem is that parents often have very strange ideas as to what constitutes a 'gentle tap' and their children may well not agree with their definitions. 
Other family factors, such as conflict, especially violent conflict between parents, poor quality supervision, and neglect, are of major significance in the background of children and adolescence showing violent behaviour.

\section{(C) SCHOOL FACTORS}

Schools differ in the degree of which they protect against or exacerbate aggressive behaviour. ${ }^{9}$ Better organised schools will, after correction for the social pattern of their intake, produce three or four times fewer delinquents than poorly organised and managed schools.

Schools are also, however, places in which children are exposed to aggressive behaviour from their peers. In the $\mathrm{UK}$, serious bullying has been reported at some time over the previous term by one in four junior and middle school pupils and about one in 10 secondary school pupils. ${ }^{10}$

\section{(D) THE MEDIA}

It is now reasonably well established that exposure to violent images on television or video increases the risk of later violence. ${ }^{11}$ The effect is not great and accounts for between $5-15 \%$ of the variance. The better studies have obtained consistent variance contributions of this dimension. The effects are likely to be greatest with children aged around 8 to 11 years when the media violence to which they are exposed is lifelike and easy to identify with.

\section{(E) GENETIC FACTORS}

Twin studies suggest genetic factors are of only minor importance as a background factor in antisocial behaviour in childhood and adolescence. However, there may be a very significant genetic contribution in that relatively small number of individuals whose aggressive behaviour continues into adulthood. ${ }^{12}$

\section{(F) GENDER}

Violence is largely a male preserve. The reasons for this probably lie largely in the different upbringing of the two sexes.

\section{(G) TEMPERAMENT AND PREDISPOSING PSYCHIATRIC DISORDERS}

Certain personality characteristics and related psychiatric disorders put a boy at risk for antisocial behaviour ${ }^{13}$ and probably for violence. In particular, children who show the hyperkinetic syndrome marked by impulsivity and disinhibition are especially at risk. Depression with associated low self esteem may form the basis for aggressive and occasionally for violent behaviour.

\section{(H) ALCOHOL}

Alcohol is a major background factor in much domestic violence to which children are often witness and in which they are sometimes directly involved as victims. The 1992 British crime survey, ${ }^{14}$ based on victim reports, reveals that in $39 \%$ of cases of domestic violence the offender was drunk.

\section{Possibilities for prevention}

SOCIAL AND ECONOMIC INTERVENTIONS

Government policies to reduce poverty, income inequalities, eradicate homelessness, and ensure status enhancing work (if possible in paid employment) would, if successful, have a significant impact on rates of violence in children and young people. The means by which such socially desirable ends can be achieved are, of course, arguable. But, at the time of writing, there is a growing consensus that leaving the fate of the socially disadvantaged to the vagaries of a free market system is unlikely to do anything other than exacerbate the problem.

Various other social and fiscal policies could also be seen as likely to lead to a reduction in violence. Increasing the real cost of alcohol through taxation, ${ }^{15}$ and censoring videos and television programmes featuring gratuitous violence, could be expected to have small but measurable effects.

Although making the use of physical punishment in the home a criminal offence is probably unrealistic at the present time, a government sponsored public education programme aimed at the eventual abolition of this form of discipline in favour of more positive methods, would have much to commend it.

\section{PERSONAL INTERVENTIONS}

\section{(A) PRECONCEPTUAL MEASURES}

Preparation for parenthood is currently given inadequate attention in secondary schools and does not feature as a compulsory subject in the national curriculum. There is quite enough solid knowledge on child development and family functioning for the introduction of such a subject, initially on an experimental basis as an examinable subject. Information on the prevention of unwanted conception would be an important component, and techniques of achieving a reduction in risky behaviour have been evaluated and found to be effective. ${ }^{16}$

\section{(B) PREGNANCY}

This is also a time when opportunities can be taken for parent education with strong emphasis on problems relating to breast feeding and lack of sleep in the first few weeks after birth. Too often parents are quite unprepared for this exhausting phase of life and consequently fail to plan for it by ensuring help from family and friends beforehand. Discussion of variation in infant temperament can also be helpful at this time.

\section{(C) POSTNATAL PERIOD}

The first year after birth is crucial to the development of satisfying parent-child interactions, protective against subsequent behaviour problems. For isolated vulnerable and depressed mothers, the intervention of health visitors can make a demonstrable positive impact (L Murray et al, personal communication). Putting mothers in contact with local self help groups can also prove useful. In both the postnatal and preschool periods, the availability of a more skilled and better resourced child protection service to identify physically abused children and provide effective family support or, if necessary, high quality substitute care, would reduce subsequent rates of violence in the children themselves.

(D) THE PRESCHOOL PERIOD

During the period from 1 to 5 years, difficult behaviour predictive of later antisocial problems, including violence, first becomes apparent. There is strong continuity between behaviour problems characterised by restless, unusually disobedient behaviour at 3 years, and antisocial behaviour at 8 years. ${ }^{17}$ This type of behaviour is more predictive of later aggressive behaviour than any other factor or group of factors such as marital conflict or parental depression. 
Consequently this is the first opportunity for secondary prevention, and paediatricians who are in the forefront of health care at this age can make helpful interventions. They can themselves provide counselling to parents with principles of child centred care, the avoidance of physical punishment, and a positive approach to discipline. Alternatively they can refer to others who can provide such counselling. Where appropriate and practicable they can involve other agencies, such as social services or child psychiatry. ${ }^{19}$ If appropriate, they can try to facilitate placement in the best educational or social service establishments locally available. There is good evidence from studies carried out in the US that effective preschool educational programmes can result in significantly diminished rates of delinquency as long as 15 years later, ${ }^{19}$ and it is likely that high quality, universally available preschool education in the UK from 3-5 years would also result in reduced antisocial behaviour later on.

\section{(E) PRIMARY SCHOOL AGE}

Aggressive behaviour in primary school is often linked to, and may be caused by, educational failure. ${ }^{20}$ The introduction of regular testing at 7 years means that it is now unusual for early reading difficulties to go undetected. Remedial education resources are, however, quite inadequate. The provision of such resources would make a significant impact on rates of difficult behaviour.

It has now been clearly demonstrated that the implementation of effective antibullying policies in schools results in a marked diminution of this unpleasant feature of school life. ${ }^{21}$ The Department for Education recently issued helpful guidelines to schools in England and Wales on this issue. ${ }^{22}$ Antibullying policies represent one of the few forms of preventive intervention that have been subjected to controlled trials with positive results.

\section{(F) SECONDARY SCHOOLS}

By this age, violent behaviour in children is usually well established, and primary prevention is largely irrelevant, though the availability of well resourced and managed outof-school activity centres, especially geared to the nonacademic youngster have been shown to reduce rates of delinquency. ${ }^{23}$

Secondary prevention is difficult. Although there are some circumstances in which treatment strategies at this age are effective, especially when the child and family are motivated to receive help, seriously aggressive adolescents present chronic problems for which it is more appropriate to think in terms of care aimed at limiting disability in the children themselves and in other family members than in cure. The aims of counselling and referral to specialist services therefore need to be modest and realistic. ${ }^{2}$

\section{Role of paediatricians}

Paediatricians may well ask whether it is reasonable to expect them to make a significant contribution to the prevention of violent behaviour in children. Clearly there is an important role for the paediatrician in counselling parents of preschool children with restless, disobedient behaviour, or in arranging for others to deliver such counselling, and pushing for the development of such a service if it does not already exist.
Paediatricians may, in the course of their work, identify children with violent behaviour, usually as one feature of an antisocial disorder. Very occasionally such children will have conditions such as epilepsy that are amenable to medical treatment. Much more commonly this will not be the case, and such children should be appropriately referred. If gratuitous cruelty forms part of the pattern of behaviour, referral to child psychiatric services will be indicated.

In addition, paediatricians, who are often regarded as experts in child care as well as childhood illness, should take their positions as role models seriously. Toy guns and videos containing violent material should be banned from children's outpatients and hospital wards. The use of physical punishment by parents should be discouraged because it is often ineffective and potentially harmful. Paediatricians can certainly play a part in changing attitudes in our society so that, over the next decade, violence becomes a totally unacceptable way to resolve conflicts in parent-child and child-child disputes.

Developmental Psychiatry Section,

PHILIP GRAHAM

Department of Psychiatry,

University of Cambridge,

Douglas House,

186 Trumpington Road

Cambridge CB2 $2 A H$

1 Gulbenkian Foundation. Report of the commission on violence in children and young people. London: Gulbenkian Foundation, 1995.

Kazdin AE. Conduct disorders in childhood and adolescence. Developmental clinical psychology and psychiatry. 2nd Ed. London: Sage Publications, 1995.

3 Smith DJ. Youth crime and conduct disorders: trends, patterns and causal explanations. In: Rutter M, Smith D, eds. Psychosocial disorders in young people: time trends and their causes. Chichester: Wiley, 1995: 389-489.

4 Farrington DP. The challenge of teenage antisocial behaviour. In: Rutter M, ed. Psychosocial disturbances in young people: challenges for prevention. Cambridge: Cambridge University Press, 1995: 83-130.

5 Kolvin I, Miller FJW, Scott DM, Gatzanis SRM, Fleeting M. Continuities of deprivation? The Newcastle 1000 family study. Aldershot: Avesbury, 1990.

deprivation? The Newcastle 1000 family study. Aldershot: Avesbury, 1990.
Belson WA. Television violence and the adolescent boy. Westmead: Saxon House, 1978

7 Sampson RJ, Laub JH. Crime in the making: pathways and turning points through life. Cambridge, MA: Harvard University Press, 1993.

8 Widom CS. Does violence beget violence? A critical examination of the literature. Psychol Bull 1989; 106: 3-28.

9 Mortimore $P$. The positive effects of schooling. In: Rutter M, ed. Psychosocial disturbances in young people: challenges for prevention. Cambridge: Cambridge University Press, 1995: 333-63.

10 Whitney I, Smith PK. A survey of the nature and extent of bullying in junior/middle and secondary schools. Educational Research 1993; 35: 3-25.

11 Comstock G, Paik H. Television and the American child. New York: Academic Press, 1991.

12 DiLalla LF, Gottesman II. Heterogeneity of causes of delinquency and criminality: life span perspectives. Development and Psychopathology 1989; 1: 339-49.

13 Reitsma-Street M, Offord DR, Finch T. Pairs of same-sex siblings discordant for antisocial behaviour. Br $\mathcal{F}$ Psychiatry 1985; 146: 415-23.

14 Mayhew P, Maughan NA, Mirrlees-Black C. The 1992 British crime survey. London: HMSO, 1992.

15 Edwards G, Anderson P, Babor TF, et al. Alcohol policy and the public good. Oxford: Oxford University Press, 1995

16 Mellanby AR, Phelps FA, Crichton NJ, Tripp JH. School sex education: an experimental programme with educational and medical benefit. $B M F$ 1995; 311: 414-7.

17 Richman N, Stevenson J, Graham P. Preschool to school: a behavioural study. London: Academic Press, 1982.

18 Graham P. Types of psychiatric treatment: an overview. In: Garralda ME, ed. Managing children with psychiatric problems. London: BMJ Publishing Group, 1993: 20-1.

19 Berrueta-Clement JR, Schweinhart LJ Barnett WS, Weikart DP The effects of early educational intervention on crime and delinquency in effects of early educational intervention on crime and delinquency in adolescence and early adulthood. In: Burchard JD, Burchard

20 Rutter M, Tizard J, Whitmore K. Education, health and behaviour. London: Longmans, 1970.

21 Olweus D. Bully victim problems among schoolchildren: basic facts and effects of a school based intervention programme. In: Rubin K, Pepler D, eds. The development and treatment of childhood aggressive behaviour. Hillsdale, NJ: Lawrence Erlbaum, 1989.

22 Department for Education. Bullying: don't suffer in silence - an anti-bullying pack for schools. London: HMSO, 1995.

23 Jones MB, Offord DR. Reduction of antisocial behaviour in poor children by non-school skill development. F Child Psychol Psychiatry 1989; 30: 737-50. 